\title{
A Bíblia e a sua Mensagem: introdução à leitura e ao estudo da Bíblia
}

FERnANDES, Leonardo Agostini: Rio de Janeiro: Editora Puc-Rio e Editora

Reflexão, 2010.

(223 páginas)

Geraldo Dondici Vieira

\section{Introdução}

Reunindo especiarias finas e ajuntando cada ingrediente no momento exato com maestria, Pe. Leonardo Agostini oferece ao leitor acadêmico da Bíblia e ao leitor fiel das comunidades um instrumento de pesquisa e de aprimoramento da fé precioso e que, já há muito tempo, se fazia necessário.

As informações históricas, literárias e exegéticas do texto bíblico apresentadas de forma sucinta, eficiente e precisa, colocadas ao lado de preciosas indicações hermenêuticas e pedagógicas, constituem os fundamentos metodológicos a sustentarem toda a novidade comunicativa do livro.

Uma obra tão especial e um instrumento de tal força catequética pedem uma resenha que ao menos toque o horizonte científico-pastoral dentro do qual o gênero literário e as conclusões teológicas do livro apóiam-se.

\section{As 26 conclusões}

Os doze capítulos de "A Bíblia e a sua Mensagem" conduzem o leitor em uma viagem inter-continental. Na verdade, trata-se de uma expedição de pesquisa, de reconhecimento de campo e de aprofundamento espiritual. Poderia ser chamada de: "o caminho de Abraão a Jesus", ou mesmo, "do monte Moriá ao monte Calvário". 
Tendo cumprido o percurso, o pesquisador e leitor terão percorrido um roteiro de viagem que os fizeram visitar, reconhecer e aprofundar estes 26 pontos essenciais, como indicados no capítulo XII:

1)A Bíblia é uma biblioteca; 2) Os vários gêneros literários e sua ambientação; 3) O plano divino da Salvação; 4) O Deus da Aliança e a história de Israel; 5) A vida do Povo de Israel na cultura do Crescente Fértil; 6) Os profetas de Israel contra os ídolos e as injustiças; 7) O Exílio como fratura; 8) O Exílio, fonte de re-elaboração de Tradições; 9) A linguagem teológica da Bíblia; 10) Promessas e a esperança messiânica; 11) A Encarnação do verbo: Jesus de Nazaré, o Filho de Deus; 12) A obra redentora de Jesus: sua morte e ressurreição; 13) Ler a Bíblia hoje: teologia e ciência; 14) A linguagem do passado e seu sentido hoje; 15) As grandes interrogações do homem respondidas pela Bíblia; 16) Ambiente histórico-cultural, sua influência sobre o texto bíblico e as Tradições Antigas; 17) Ler a Bíblia em seu contexto vital e literário; 18) Os hagiógrafos serviram-se de vários gêneros literários e símbolos tomados dos povos vizinhos; 19) Importância da arqueologia; 20) A Bíblia, tanto na Antiga como na Nova Aliança, entende que Deus se fez conhecer pelos homens; 21) A revelação de Deus se deu paulatinamente até culminar e completar-se em Jesus Cristo; 22) Deus edificou a fé de Israel em preparação ao advento do seu Filho; 23) Ler a Bíblia hoje é reconhecer a mesma atuação de Deus na história; 24) Ler a Bíblia para o cristão é continuar reescrevendo a história através da fé em Jesus Cristo, Filho de Deus encarnado; 25) Jesus Cristo veio mostrar que o Reino de Deus é acessível por meio da sua entrega total ao Pai a favor dos homens; 26) As palavras e ações de Jesus Cristo mostraram que ele era digno de crédito: "ele passou fazendo o bem" (At 10,38c).

Atentos a estas indicações e exercitando nelas, adquire-se aquela competência hermenêutica e teológica capaz de gerar uma leitura profícua da Bíblia.

\section{Um caminho passo a passo}

Para se chegar a operar com destreza e eficiência, as indicações e princípios apresentados no capítulo XII e elencados acima, são oferecidos onze roteiros de estudo, pesquisa e aprofundamento distribuídos pelos 11 capítulos do livro.

Os quatro primeiros capítulos (I ao IV) ocupam-se de questões propedêuticas e introdutórias ao estudo da Bíblia. Enfrentado questões básicas, como partes da Bíblia, línguas bíblicas, traduções e como citar a Bíblia etc. 
Constituem grande ajuda para o leitor iniciante e fonte de pesquisa para o leitor experiente.

Elevando-se como um cume na primeira parte do livro, o quinto capítulo retoma, a partir da Dei Verbum, a riqueza teológica da inspiração divina da Bíblia. Quatro marcantes conclusões tecem o vasto horizonte da inspiração divina da Bíblia: 1) Todos os livros da Bíblia são inspirados e trazem neles a verdade sobre Deus; 2) Todas as palavras bíblicas são inspiradas, porque nasceram da luz do Espírito Santo sobre as mentes e as vontades dos autores sagrados; 3) O carisma da inspiração integra o mundo da Bíblia e seus personagens com a Igreja no mundo inteiro e seus fiéis; 4) A Bíblia está penetrada pela potência do Espírito Santo que revela os segredos de Deus aos fiéis.

Após esta primeira parte propedêutica e teológica, o livro conduz seu leitor para dentro do mundo hermenêutico e exegético da Bíblia. No capítulo VI as tábuas geográficas do mundo bíblico e as linhas essenciais da história de Israel são disponibilizadas como contexto essencial para a leitura proveitosa do texto bíblico. O capítulo VIII possibilita a visita ao momento mais significativo da história do povo de Israel: o exílio da Babilônia (586/587 a 538 a.C). As consequências teológicas, políticas, sociais, culturais e literárias do Exílio transformam profundamente a vida e as esperanças do Povo de Israel.

Os capítulos IX e X fornecem importantes chaves hermenêuticas, literárias e teológicas de cada um dos livros da Bíblia. Os livros do Antigo Testamento são apresentados dentro dos quatro grandes conjuntos de tradições: Pentateuco; Livros Históricos; Livros Sapienciais; Livros Proféticos. Os livros do Novo Testamento recebem um tratamento semelhante, mas são divididos segundo os grandes gêneros literários guardados pela Tradição: Evangelhos, Atos dos Apóstolos, Epístolas e Apocalipse.

Como convite a uma leitura contínua da Bíblia, o capítulo XI põe em foco o texto de cada um dos livros da Bíblia e sugere a oração de um salmo para aprofundar a meditação do texto bíblico estudado e acolhido.

\section{Um método de estudo}

Os oito primeiros capítulos, que juntos compõem o conjunto de informações hermenêuticas para o estudo da Bíblia, trazem sempre ao final de cada capítulo perguntas fundamentais para fixar bem o tema estudado. As perguntas e os exercícios servem para a avaliação imediata, aprofundamento 
necessário, memorização dos elementos centrais e organização de estudos bíblicos em grupos ou escolas bíblicas.

Os capítulos que apresentam os livros da Bíblia (IX, X, XI) somente podem ser entendidos plenamente se acompanhados lado a lado da leitura do texto bíblico. $\mathrm{Na}$ verdade, estes três capítulos formam um guia essencial de leitura da Bíblia.

\section{Segredos revelados e portas abertas}

Alguns pequenos segredos de "A Bíblia e a sua mensagem" deixam-se transparecer de modo carinhoso e singelo. O primeiro segredo é revelar-se como guia de leitura da Palavra de Deus, e não se aceita senão na condição de abrir caminhos para leitura atenta e efetiva da Bíblia. O segundo segredo é incentivar o leitor a continuar seus estudos bíblicos, utilizando-se de uma bibliografia indicada a cada passo, e também convidando a compor um vocabulário bíblico pessoal, podendo-se servir das linhas disponíveis em cada página. O terceiro segredo está estampado nas páginas 13 e 223. Duas belas orações que fazem o papel de inclusão de todo o livro. Com isto, aprende-se que a leitura da Bíblia somente torna-se viva e eficaz dentro do contexto da oração pessoal e comunitária.

\section{A Lectio Divina}

"A Bíblia e a sua mensagem" chega em bom momento para sustentar o exercício tradicional da Lectio Divina (VD 86). A carência de informações básicas sobre a Bíblia, o risco de leituras fundamentalistas, a superficialidade de uma leitura da Bíblia sem o seu ambiente vital (contexto) e a ameaça de uma leitura marcada por ideologias podem empobrecer ou anular os frutos da leitura. Todos estes riscos e ameaças são evitados com a utilização dos conteúdos e da proposta metodológica do livro do Pe. Leonardo Agostini Fernandes.

\section{Verbum Domini}

Mesmo que a obra tenha sido publicada antes do documento oficial do Sínodo dos Bispos sobre a Palavra de Deus na vida e na missão da Igreja, as propostas e a metodologia de "A Bíblia e sua Mensagem" estão em plena consonância com o que ensina o Santo Padre Bento XVI: 
Nesta linha, o Sínodo convidou a um esforço pastoral particular para que a Palavra de Deus apareça em lugar central na vida da Igreja, recomendando que se "incremente a pastoral bíblica", não em justaposição com outras formas da pastoral, mas como animação bíblica da pastoral inteira (VD 73).

"A Bíblia e a sua mensagem" chega até o leitor da Bíblia e as comunidades de fé como poderoso e eficaz instrumento para ajudar na animação bíblica de toda pastoral, de toda espiritualidade e de toda a vida da Igreja.

Geraldo Dondici Vieira

Doutor em Teologia Bíblica pela FAJE-BH Professor do Departamento de Teologia da PUC-Rio 